\title{
PERTEMUAN SABAR DAN SYUKUR DALAM HATI
}

\author{
Akhmad Sagir \\ Dekan Fakutas Dakwah dan Komunikasi \\ IAIN Antasari Banjarmasin
}

\begin{abstract}
Gratitude and patience are two characters/attitudes that exists in every buman being, there is one among us has misunderstanding and misinterpret on both the characters/attitudes. When both are brought into the real of social reality filled with romance and the problems of life. It is commonplace to understand that patience and gratitude are opposite attitude, both appears motivated by different circumstances. Patience usually will come out when someone gets something terrible that makes him uncomfortable. Instead of gratitude will occur if something comes to him to make him happy, excited and others for instance. This paper attempts to analyze both cases and meeting between both of characters/attitudes are in the heart of every buman being.
\end{abstract}

Kata kunci: Kesabaran, Syukur, Hati, Sikap

\section{Pendahuluan}

Kehidupan yang kita jalani sejak dulu hingga sekarang, kadang-kadang mengarah kepada hal yang baik-baik atau sesuai dengan keinginan diri, tetapi kadang juga ada yang tidak baik atau tidak sesuai dengan harapan. Segala sesuatu yang sebelumnya kita rencanakan terlebih dahulu pun kadang-kadang tidak berjalan sesuai dengan apa direncanakan namun juga bisa sebaliknya hal yang tidak direncanakan namun mendapatkan hasil yang baik bahkan seperti yang diharapkan. Ada halangan dan rintangan yang dihadapi dan juga ada stimulus dalam menghadapi kehidupan ini.

Segala makhluk apapun yang ada di dunia ini tidak ada yang sempurna, pasti setiap manusia yang menjalani kehidupan di dunia ini pernah merasakan susah, rugi, dan hampir putus asa. Dan pasti juga pernah merasakan senang, untung dan gembira. Namun segala kesusahan yang dirasaskan janganlah dijadikan alasan untuk menjadi manusia yang malas, manusia yang mudah menyerah sebelum melakukan usaha, sementara kesenangan dan kegembiraan tidak lantas membuat seseorang lupa daratan, karena sesungguhnya penilaian Allah bukan pada keberhasilan yang diraih, tapi mindset, proses usaha yang kita jalani demi memberikan hasil yang sebaikbaiknya, juga hati yang selalu ingat kepada Sang Pengatur dan Pemberi.

Sikap sabar dan syukur seharusnya dimiliki oleh setiap manusia, dan merasuk dalam hati setiap orang. Dua sikap yang sebaiknya tidak dipisahkan bahkan dapat dipertemukan dalam hati setiap insan, karena memang ia dipergunakan berdasarkan situasi dan kondisi yang mungkin berbeda sehingga cara menyikapinya berbeda. Namun tidak semua orang sama sikapnya dalam menyikapi suatu keadaan dan disinilah pertemuan kedua sikap itu dalam hati manusia. 


\section{Pembahasan}

\section{Definisi Sabar dan Syukur}

\section{a. Sabar}

Asal kata sabar adalah al-man'u berarti menahan dan al-habsu berarti mencegah.Jadi, sabar adalah menahan dan mencegah dari perbuatan yang mengarah kepada keburukan dalam keadaan sempit ${ }^{1}$. Sabar juga berasal dari kata "Shabara-Yashburu-Shabaran": yaitu ketundukan penerimaan apa-apa yang telah Allah berikan baik kesenangan atau kesedihan².

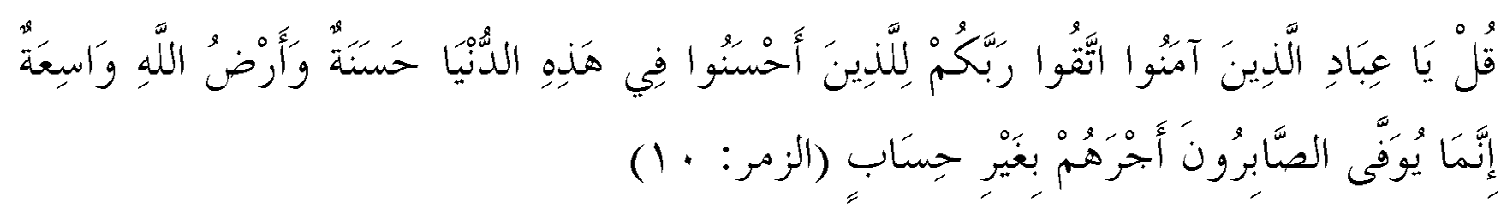

Katakanlah: "Hai hamba-hamba-Ku yang beriman. bertakwalah kepada Tubanmu". orang-orang yang berbuat baik di dunia Ini memperoleh kebaikan. dan bumi Allah itu adalah luas. Sesunggubnya Hanya orang-orang yang Bersabarlah yang dicukupkan pahala mereka tanpa batas.

Lain lagi menurut syeikh Ibnu Qoyyim Al-jauziyah, bahwa sabar merupakan budi pekerti yang bisa dibentuk oleh seseorang. Ia menahan nafsu, menahan sedih, menahan jiwa dari kemarahan, menahan lidah dari merintih kesakitan, dan juga menahan anggota badan dari melakukan yang tidak pantas. Sabar merupakan ketegaran hati terhadap takdir dan hukum-hukum syari'at.

Terkadang kita meyakini bahwa kesabaran mempunyai titik batas sehingga kalau sudah melebihi batasnya manusia boleh melakukan apapun.Tapi bukan seperti ini tujuannya, semua yang telah kita kerjakan harus kembali kepada Allah SWT sebagai dasar atas segala perilaku yang kita kerjakan. Hal ini dapat memberikan nilai positif bagi diri kita sendiri, karena segala sesuatu yang kita kerjakan atas nama Allah SWT pasti yang dikerjakan akan mengarah kepada yang baik. Sikap sabar juga merupakan sikap dasar dari ciri-ciri orang yang bertaqwa.

Sabar pada hakikatnya merupakan sebuah pembelajaran dari bagaimana kita menyikapi sesuatu hal yang kita alami. Misalkan saja, kita dalam kondisi yang tidak baik, lalu kita berusaha untuk keluar dalam keadaan tersebut. Sabar itu merupakan perwujudan dari apa yang kita usahan dari sesuatu yang tidak baik menjadi baik. "Sabar itu indah", dan "Sabar itu cahaya".

\section{b. Syukur}

Kata "syukur" adalah kata yang berasal dari bahasa Arab. Kata ini dalam Kamus Besar Bahasa Indonesia diartikan sebagai: (1) rasa terima kasih kepada Allah, dan (2) menyatakan lega, senang, dan sebagainya.

Pengertian kebahasaan ini tidak sepenuhnya sama dengan pengertiannya menurut asal kata itu maupun menurut penggunaan Al-Quran atau istilah keagamaan. Yang mana kata "syukur" dengan berbagai bentuknya ditemukan sebanyak enam puluh empat kali. Ahmad Ibnu Faris dalam bukunya Maqayis Al-Lughah ${ }^{3}$ menyebutkan empat arti dasar dari kata tersebut yaitu, 1).

${ }^{1}$ al-Raghib al-Ashfahani, Mu'jam Mufradat AlFaz̧ al-Qur'an, (Beirut: Dar al-Fikr, t.th.), h. 280.

${ }^{2}$ al-Raghib al-Ashfahani, Mu'jam Mufradat,. h. 280

${ }^{3}$ Abu Husayn Ahmad b. Faris b. Zakariya, Mujam Maqayis al-Lughah, (Bayrut: Dar al-Jalil, Jilid II, 1411 H/1991 M.), hlm. 250 . 
Pujian karena adanya kebaikan yang diperoleh; 2) Kepenuhan dan kelebatan. Pohon yang tumbuh subur dilukiskan dengan kalimat syakarat asy-syajarat. 3) Sesuatu yang tumbuh di tangkai pohon (parasit). 4) Pernikahan, atau alat kelamin.

Agaknya kedua makna terakhir ini dapat dikembalikan dasar pengertiannya kepada kedua makna terdahulu.Makna ketiga sejalan dengan makna pertama yang mengambarkan kepuasan dengan yang sedikit sekalipun, sedang makna keempat dengan makna kedua, karena dengan pernikahan (alat kelamin) dapat melahirkan banyak anak.

Makna-makna dasar tersebut dapat juga diartikan sebagai penyebab dan dampaknya, sehingga kata "syukur" mengisyaratkan "Siapa yang merasa puas dengan yang sedikit, maka ia akan memperoleh banyak, lebat, dan subur."

Adapun kata syukur menurut al-Raghib al-Isfahani, mengandung arti "gambaran dalam benak tentang nikmat dan menampakkannya ke permukaan", karena kata itu menurut sebagian ulama berasal dari kata "syakara" yang berarti membuka, sehingga merupakan lawan dari kata "kafara" yang berarti "menutup" dan mengandung makna melupakan nikmat dan menutup-nutupinya.

Hakikat syukur adalah "menampakkan nikmat," dan hakikat kekufuran adalah menyembunyikannya. Menampakkan nikmat berarti menggunakannya pada tempat yang tepat dan sesuai dengan yang dikehendaki oleh pemberinya, juga menyebut-nyebut nikmat dan pemberinya dengan lidah, seperti firman Allah berikut:

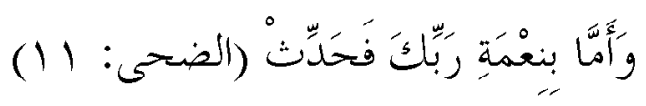

"Adapun terbadap nikmat Tubanmu, maka hendaklah engkau menyebut-nyebut (QS Adh-Dhuba [93]: ll).

Sementara ulama ketika menafsirkan firman Allah, "Bersyukurlah kepada-Ku dan janganlah kamu mengingkari (nikmat)-Ku" (QS Al-Baqarah [2]: 152) Menjelaskan bahwa ayat ini mengandung perintah untuk mengingat Tuhan tanpa melupakannya, patuh kepada-Nya tanpa menodainya dengan kedurhakaan. Syukur orang demikian lahir dari keikhlasan kepada-Nya, dan karena itu, ketika setan menyatakan bahwa, "Demi kemuliaan-Mu, Aku akan menyesatkan mereka (manusia) semuanya" (QS Shad [38]: 82), dilanjutkan dengan pernyataan pengecualian, yaitu, "kecuali hamba-hamba-Mu yang mukhlash di antara mereka" (QS Shad [38]: 83). Dalam QS Al-A'raf (7): 17 Iblis menyatakan, "Dan Engkau tidak akan menemukan kebanyakan dari mereka (manusia) bersyukur." Kalimat “tidak akan menemukan” di sini serupa maknanya dengan pengecualian di atas, sehingga itu berarti bahwa orang-orang yang bersyukur adalah orangorang yang mukhlish (tulus hatinya).

\section{Macam-macam Sabar dan Syukur}

\section{a. Sabar}

Rasa sabar dan syukur yang dimiliki oleh setiap insan itu tentu saja berada pada segmentasi yang berbeda-beda. Oleh karenanya keduanya terbagi kepada beberapa macam berdasarkan pandangan para ulama seperti: 
Menurut Imam al-Qusyairi ${ }^{5}$, sabar itu terbagi kepada beberapa macam: 1) sabar di atas upaya sebagai hamba; 2) sabar terhadap sesuatu di luar upaya hamba. Adapun sabar yang dapat diupayakan yaitu dalam rangka ta'at menjalankan perintah Allah maupun menjauhi laranganNya. Dan sementara sabar terhadap sesuatu yang diluar keupayaan hamba, seperti kesulitan dalam menggapai hal-hal yang berhubungan dengan hukum-hukum Allah Swt.

Senada dengan yang dikemukakan Imam al-Qusyairi di atas, Al-Mukarram K.H. Muhammad Bakhit, ketika menjelaskan tentang ma'rifat kepada Allah Swt, melalui mengenal nama Allah "al-Shabur". Beliau menyatakan bahwa "Orang beriman yang sabar, yaitu sabar atas tiga perkara: 1) Sabar atas musibah; 2) sabar dalam melaksanakan ta’at; dan 4) sabar dalam menghadapi ma'siat/dosa ${ }^{6}$.

\section{1) Sabar atas musibab}

Musibah yang dimaksud adalah bencana yang diakibatkan dari perbuatan maksiat kepada Allah SWT.Musibah yang diberikan Allah kepada umatnya merupakan salah satu wujud bahwa Allah SWT selalu memperhatikan segala sesuatu yang dikerjakan.Musibah juga merupaka teguran yang diberikan Allah agar manusia selalu mengingat serta mensyukuri segala sesuatu yang diberikan Allah kepada umatnya.Allah memberikan musibah kepada umatnya adalah sebagai landasan agar manusia selalu introspeksi diri serta selalu bertaubat, memohon ampunan dari Allah SWT.

\section{2) Sabar dalam mengerjakan Ibadab dan Taat}

Sabar dalam taat atau dalam istilah lain beramal sholeh sangat diperukan karena betapa banyak yang harus dikorbankan dalam kehidupan untuk melaksanakan taat kepada Allah Swt. Apabila tidak dilandasi dengan kesabaran dan kesungguhan, maka mungkin saja taat ibadah dan amal shaleh yang dilakukannya hanya bersifat sementara, padahal taat itu tidak cukup sekali atau dua kali, tetapi ia membutuhkan istiqamah apalagi ta'at ibadah tersebut memang bersifat rutin harus dilaksanakan.

\section{3) Sabar atas Ma'siat}

Sabar atas maksiat ini maksudnya adalah sabar atas yang diharamkan oleh Allah Swt ${ }^{7}$. seperti kita sedang bertemanan yang menggibah orang lain, kita tahu bahwa gibah itu dosa besar, tetapi kadang-kadang kita juga ingin mendengarkan dan bahkan ikut membenarkannya, di situlah kita perlu sabar. Apabila kita tidak bisa menegurnya maka kita harus meninggalkan atau menjauhinya.

Begitu juga mungkin kita mempunyai peluang yang menguntungkan, namun kita harus berbuat curang, disitulah keimanan kit adiuji apakah kita bisa menahan diri dengan sabar atau tidak. Di sinilah diperlukan kesabaran atas ma'siat. Jadi hakekat sabar itu menurut imam alGhazali adalah kuatnya dorongan agama dalam menghadapi dorongan hawa nafsunya ${ }^{8}$.

${ }^{5}$ Al-Allamah, al-Arif billah Abi al-Qasim 'Abdul Karim bin Hawazin al-Qusyairy al-Naisaburi, al-Risalah alQusyairiyyahfi Tlm al-Tashawnuf, t.tp. (Dar al-Khair, t.th.), h. 184.

${ }^{6}$ Al-Mukarram K.H. Mmuhammad Bakhit bin al-Mukarram K.H. Ahmad Mughni, Mengenal al-Asma' al-Husna: Jalan Menuju Ma'rifat Allah Swt. (Barabai HST: Pon. Pes. Dan Majlis Ta'lim Nur al-Muhibbin, t.th.), hal. 575.

${ }^{7}$ K.H. Mmuhammad Bakhit, Mengenal al-Asma' al-Husna, h. 577.

${ }^{8}$ Al-Imam Abu Hamid Muhammad bin Muhammad al-Ghazali, Kitab al-Arba'in fi Ushul al-Din, Terj. Rojaya, 40 Prinsip Agama, (Bandung: Pustaka al-Hidayah, 2002.) h. 189. 


\section{b. Syukur}

Adapun rasa syukur itu pada dasarnya terhadap segala nikmat yang diperoleh atau yang dianugerahkan kepada manusia. Nikmat diartikan oleh sementara ulama sebagai "segala sesuatu yang berlebih dari modal Anda".Adakah manusia memiliki sesuatu sebagai modal? Jawabannya, "Tidak". Bukankah hidupnya sendiri adalah anugerah dari Allah? "Bukankah telah datang atas manusia satu waktu dari masa, sedang ia ketika itu belum merupakan sesuatu yang dapat disebut? (QS Al-Insan [76]: ayat 1).

Nikmat Allah demikian berlimpah ruah, sehingga Al-Quran menyatakan, "Seandainya kamu (akan) menghitung nikmat Allah, niscaya kamu tidak akan sanggup menghitungnya (QS Ibrahim [14]: 34).

Al-Biqa'i dalam tafsirnya terhadap surat Al-Fatihah mengemukakan bahwa "alhamdulillah" dalam surat Al-Fatihah menggambarkan segala anugerah Tuhan yang dapat dinikmati oleh makhluk, khususnya manusia. Itulah sebabnya -menurut beliau- empat surat lain yang juga dimulai dengan al-hamdulillah masing-masing menggambarkan kelompok nikmat Tuhan, sekaligus merupakan perincian dari kandungan nikmat yang dicakup oleh kalimat alhamdulillah dalam surat Al-Fatihah itu. Karena Al-Fatihah adalah pembuka Al-Quran dan kandungan ayat-ayatnya dirinci oleh ayat-ayat lain.

Keempat surah yang dimaksud adalah:

Pertama, Surab Al-An'am (surat ke-6) yang dimulai dengan: "Segala puji bagi Allah Yang telahmenciptakan langit dan bumi, dan mengadakan gelap dan terang".Ayat ini mengisyaratkan nikmat wujud di dunia ini dengan segala potensi yang dianugerahkan Allah baik di darat, laut, maupun udara, serta gelap dan terang.

Kedua, Surab Al-Kabf (surat ke-18), yang dimulai dengan: "Segala puji bagi Allah yang telah menurunkan kepada hamba-Nya Al-Kitab (Al-Quran), dan tidak membuat kebengkokan (kekurangan) di dalamnya". Di sini diisyaratkan nikmat-nikmat pemeliharaan Tuhan yang dianugerahkannya secara aktual di dunia ini. Disebut pula nikmat-Nya yang terbesar yaitu kehadiran Al-Quran di tengah-tengah umat manusia, untuk "mewakili" nikmat-nikmat pemeliharaan lainnya.

Ketiga, Surab Saba' (surat ke-34), yang dimulai dengan" "Segala puji bagi Allah yang memiliki apa yang ada di langit dan apa yang ada di bumi, dan bagi-Nya pula segala puji di akhirat. Dan Dialah Yang Maha Bijaksana lagi Maha Mengetahui".Ayat ini mengisyaratkan nikmat Tuhan di akhirat kelak, yakni kehidupan baru setelah mengalami kematian di dunia, di mana dengan kehadirannya di sana manusia dapat memperoleh kenikmatan abadi.

Keempat, Surab Fatbir (surat ke-35), yang dimulai dengan: "Segala puji bagi Allah Pencipta langit dan bumi, Yang menjadikan malaikat sebagai utusan-utusan untuk mengurus berbagai macam urusan (di dunia dan di akhirat), yang mempunyai sayap masing-masing (ada yang) dua, tiga, dan empat". Ayat ini adalah isyarat tentang nikmat-nikmat abadi yang akandianugerahkan Allah kelak setelah mengalami hidup baru di akhirat. Setiap rincian yang terdapat dalam keempat kelompok nikmat yang dicakup oleh keempat surat di atas, menuntut

${ }^{9}$ Imam Ibrahim bin Umar al-Biqa'i, Nazhm al-Durarfi Tanasub al-Ayat wa al-Suwar, (t.tp, Dar al-Kitab al-Islamy), (tth.), h. 15 . 
syukur hamba-Nya baik dalam bentuk ucapan al-hamdulillah, maupun pengakuan secara tulus dari lubuk hati, serta mengamalkan perbuatan yang diridhai-Nya.

Dari keempat surah yang dikemukakan di atas secara global dikemukakan nikmat-nikmat Allah yang mengharuskan adanya syukur. Namun demikian dalam beberapa ayat yang lain disebut secara eksplisit nikmat-nikmat yang mesti disyukuri, antara lain: 1) Kehidupan dan kematian, (QS Al-Baqarah [2]: 28); 2) Hidayat Allah, (QS Al-Baqarah [2]: 185); 3) PengampunanNya, (QS Al-Baqarah [2]: 52); 4) Pancaindera dan akal, (QS An-Nahl [16]: 78); 5) Rezeki, (QS Al-Anfal [8]: 26); 6) Sarana dan prasarana antara lain, (QS An-Nahl [16]: 14); 7) Kemerdekaan (QS Al-Maidah [5]: 20)

Masih banyak lagi nikmat-nikmat lain yang secara eksplisit disebut oleh Al-Qur'an. Dalam surat Ar-Rahman (surat ke-55), Al-Quran membicarakan aneka nikmat Allah dalam kehidupan dunia ini dan kehidupan akhirat kelak. Hampir pada setiap dua nikmat yang disebutkan. Quran mengulangi satu pertanyaan dengan redaksi yang sama yaitu, "Maka nikmat Tuhanmu yang manakah yang kamu ingkari? Pertanyaan tersebut terulang sebanyak tiga puluh satu kali.

Para ulama menyusun semacam "rumus", yaitu siapa yang mampu mensyukuri nikmatnikmat Allah, maka ia akan selamat dari ketujuh pintu neraka, sekaligus dia dapat memilih pintu-pintu mana saja dari kedelapan pintu surga, baik surga pertama maupun surga kedua, baik Surga (kenikmatan duniawi) maupun kenikmatan ukhrawi.

\section{Manfaat Sabar dan Syukur}

\section{- Sabar}

Kesabaran adalah kunci agar kita selalu ditemani dan dibimbing Allah.Sabar menghantarkan seseorang menjadi manusia sejati, tangguh, elegan, dan bermartabat.Betapa banyak kerusakan yang terjadi akibat manusia tidak bisa bersabar.Banyak kegagalan perencanaan hidup juga diakibatkan karena kurangnya kesabaran.

Sabar memiliki banyak manfaat dan hikmah, di antaranya sebagai berikut.

a. Sabar Sebagai Penolong

Kesabaran bisa menjadi penolong yang akan menyelamatkan seseorang dari bahaya, baik bahaya dunia terlebih lagi bahaya akhirat.

b. Pembawa Keberuntungan

Setiap manusia normal pasti menginginkan keberuntungan. Seorang yang sedang berdagang, ia menginginkan dapat memperoleh laba yang banyak dari dagangannya. Seorang siswa, pelajar atau mahasiswa, ia menginginkan keberuntungan dengan kelulusan dari studinya, baik keberuntungan dalam arti naik kelas, naik tingkat, atau lulus plus karena memperoleh nilai yang exelence.

"Sebagaimana tersurat dalam firman Allah Swt berikut, "Hai orang-orang yang beriman, bersabarlah kamu dan kuatkanlah kesabaranmu dan tetaplah bersiap siaga dan bertakwalah kepada Allah, supaya kamu beruntung." (QS Ali Imran [3]: 200).

c. Mendatangkan Keuntungan yang Besar

Orang berdagang, lalu untung, itu biasa.Tapi, kalau pedagang yang beruntung besar, nah ini pantas menjadi berita. Inilah yang dinyatakan Allah SWT dalam Al-Qur'an: 
"Sifat-sifat yang baik itu tidak dianugerahkan melainkan kepada orang-orang yang sabar dan tidak dianugerahkan melainkan kepada orang-orang yang mempunyai keuntungan yang besar." (QS Fushshilat [41]: 35).

\section{- Syukur}

Al-Quran secara tegas menyatakan bahwa manfaat syukur kembali kepada orang yang bersyukur, sedang Allah Swt. sama sekali tidak memperoleh bahkan tidak membutuhkan sedikit pun dari syukur makhluk-Nya. Dan barangsiapa yang bersyukur, maka sesungguhnya dia bersyukur untuk (kebaikan) dirinya sendiri, dan barangsiapa yang kufur (tidak bersyukur), maka sesungguhnya Tuhanku Mahakaya (tidak membutuhkan sesuatu) lagi Mahamulia (QS An-Naml [27]: 40)

Karena itu pula, manusia yang meneladani Tuhan dalam sifat-sifat-Nya, dan mencapai peringkat terpuji, adalah yang memberi tanpa menanti syukur (balasan dari yang diberi) atau ucapan terima kasih.

Al-Quran melukiskan bagaimana satu keluarga (menurut riwayat adalah Ali bin Abi Thalib dan istrinya Fathimah putri Rasulullah saw) memberikan makanan yang mereka rencanakan menjadi makanan berbuka puasa mereka, kepada tiga orang yang membutuhkan dan ketika itu mereka menyatakan bahwa,

Sesungguhnya kami memberi makanan untukmu hanyalah mengharapkan keridhaan Allah, kami tidak menghendaki balasan darimu, dan tidak pula pujian (ucapan terima kasih) (QS Al-Insan [76]:9).

Walaupun manfaat syukur tidak sedikit pun tertuju kepada Allah, namun karena kemurahanNya, Dia menyatakan diri-Nya sebagai Syakirun 'Alim (QS Al-Baqarah [2]: 158), dan Syakiran Alima (QS An-Nisa' [4]: 147), yang keduanya berarti, Maha Bersyukur lagi Maha Mengetahui, dalam arti Allah akan menganugerahkan tambahan nikmat berlipat ganda kepada makhluk yang bersyukur. Syukur Allah ini antara lain dijelaskan oleh firman-Nya dalam surat Ibrahim (14): 7 yang dikutip di atas.

\section{Cara Bersabar dan Bersyukur}

Apabila membahas hal yang berkenaan dengan cara maka kemungkinan terjadi perbedaan adalah mungkin, oleh karena itu berikut ini diantara cara bersabar dan bersyukur:

\section{a. Sabar dan Syukur dengan hati}

Sabar dan Syukur dengan hati dilakukan dengan menyadari sepenuhnya bahwa nikmat yang diperoleh adalah semata-mata karena cobaan, anugerah dan kemurahan Ilahi. Sabar dan Syukur dengan hati mengantar manusia untuk menerima cobaan dan anugerah yang diberikan kepadanya dengan penuh kerelaan tanpa menggerutu dan keberatan bagaimanapun keadaannya.

Seorang yang bersabar dan bersyukur dengan hatinya saat ditimpa malapetaka pun, boleh jadi dapat memuji Tuhan, bukan atas malapetaka itu, tetapi karena terbayang olehnya bahwa yang dialaminya pasti lebih kecil dari kemungkinan lain yang dapat terjadi. syukur diartikan oleh orang yang bersyukur dengan "untung" (merasa lega, karena yang dialami lebih ringan dari yang dapat terjadi). 
Dari kesadaran tentang makna-makna di atas, seseorang akan tersungkur sujud untuk menyatakan perasaan syukurnya kepada Allah.Sujud syukur adalah perwujudan dari kesyukuran dengan hati, yang dilakukan saat hati dan pikiran menyadari betapa besar nikmat yang dianugerahkan Allah. Sujud syukur akan dilakukan karena betapapun musibah yang ditimpakan apalagi nikmat yang Allah anugerahkan tentunya mengandung hikmah yang besar yang masih dirahasiakan oleh Allah Swt. untuk kebaikan kita.

\section{b. Syukur dan Sabar dengan lisan}

Syukur dengan lidah adalah mengakui dengan ucapan bahwa sumber nikmat adalah Allah sambil memuji-Nya. Begitu juga dengan sabar seharusnya juga dilakukan dengan lisan. Sebagaimanapengajaran dari al-Qur'an agar pujian kepada Allah disampaikan dengan redaksi "al-hamdulillah." Al-Qur'an juga mengajarkan kalimat yang diucapkan ketika mendapat musibah dalam arti agar bersabar, yaitu “inna lillahi wa inna ilayhi rajïun”.

Hamd (pujian) disampaikan secara lisan kepada yang dipuji, walaupun ia tidak memberi apa pun baik kepada si pemuji maupun kepada yang lain. Kata "al' pada "al-bamdulillah" oleh pakar-pakar bahasa disebut al lil-istighraq, yakni mengandung arti "keseluruhan". Sehingga kata "al-hamdu" yang ditujukan kepada Allah mengandung arti bahwa yang paling berhak menerima segala pujian adalah Allah SWT, bahkan seluruh pujian harus tertuju dan bermuara kepada-Nya.

\section{c. Syukur dan Sabar dengan perbuatan}

Nabi Daud a.s. beserta putranya Nabi Sulaiman a.s. memperoleh aneka nikmat yang tiada taranya. Kepada mereka sekeluarga Allah berpesan, "Bekerjalah wahai keluarga Daud sebagai tanda syukur! (QS Saba [34]: 13). Yang dimaksud dengan bekerja adalah menggunakan nikmat yang diperoleh itu sesuai dengan tujuan penciptaan atau penganugerahannya.

Ini berarti, setiap nikmat yang diperoleh menuntut penerimanya agar merenungkan tujuan dianugerahkannya nikmat tersebut oleh Allah. Ambillah sebagai contoh lautan yang diciptakan oleh Allah SWT Ditemukan dalam Al-Quran penjelasan tentang tujuan penciptaannya melalui firman-Nya: Dialah (Allah) yang menundukkan lautan (untuk kamu) agar kamu dapat memakan darinya daging (ikan) yang segar, dan (agar) kamu mengeluarkan dan lautan itu perhiasan yang kamu pakai, dan kamu melihat bahtera berlayar padanya, dan supaya kamu mencari karuniaNya (selain yang telah disebut) semoga kamu bersyukur (QS An-Nahl [16]: 14).

Ayat ini menjelaskan tujuan penciptaan laut, sehingga mensyukuri nikmat laut, menuntut dari yang bersyukur untuk mencari ikan-ikannya, mutiara dan hiasan yang lain, serta menuntut pula untuk menciptakan kapal-kapal yang dapat mengarunginya, bahkan aneka pemanfaatan yang dicakup oleh kalimat "mencari karunia-Nya".

Di sisi lain, lanjutan ayat di atas menjelaskan bahwa "Kalau kamu kufur (tidak mensyukuri nikmat atau menutupinya tidak menampakkan nikmatnya yang masih terpendam di perut bumi, di dasar laut atau di angkasa), maka sesungguhnya siksa-Ku amat pedih.”

Suatu hal yang menarik untuk disimak dari redaksi ayat ini adalah kesyukuran dihadapkan dengan janji yang pasti lagi tegas dan bersumber dari-Nya langsung (QS Ibrahim [14):7) Tetapi akibat kekufuran hanya isyarat tentang siksa; itu pun tidak ditegaskan bahwa ia pasti akan menimpa yang tidak bersyukur(QS Ibrahim [14]:7). 
Siksa dimaksud antara lain adalah rasa lapar, cemas, dan takut. Allah telah membuat satu perumpamaan (dengan) sebuah negeri yang dahulunya aman lagi tenteram, rezekinya datang kepadanya melimpah ruah dari segenap penjuru, tetapi (penduduknya) kufur (tidak bersyukur atau tidak bekerja untuk menampakkan) nikmat-nikmat Allah (yang terpendam). Oleh karena itu, Allah menjadikan mereka mengenakan pakaian kelaparan dan ketakutan disebabkan oleh perbuatan (ulah) yang selalu mereka lakukan (QS An-Nahl [16]: 112).

Pengalaman pahit yang dilukiskan Allah ini, telah terjadi terhadap sekian banyak masyarakat bangsa, antara lain, kaum Saba — satu suku bangsa yang hidup di Yaman dan yang pernah dipimpin oleh seorang Ratu yang amat bijaksana, yaitu Ratu Balqis Surat Saba (34): 15-19 menguraikan kisah mereka, yakni satu masyarakat yang terjalin persatuan dan kesatuannya, melimpah ruah rezekinya dan subur tanah airnya. Negeri merekalah yang dilukiskan oleh AlQuran dengan baldatun thayyibatun wa Rabbun Ghafur. Mereka pulalah yang diperintah dalam ayat-ayat tersebut untuk bersyukur, tetapi mereka berpaling dan enggan sehingga akhirnya mereka berserak-serakkan, tanahnya berubah menjadi gersang, komunikasi dan transportasi antar kota-kotanya yang tadinya lancar menjadi terputus, yang tinggal hanya kenangan dan buah bibir orang saja.Demikian uraian Al-Quran. Dalam konteks keadaan mereka, Allah berfirman,

Demikianlah Kami memberi balasan kepada mereka disebabkan kekufuran (keengganan bersyukur) mereka. Kami tidak menjatuhkan siksa yang demikian kecuali kepada orang-orang yang kufur(QS Saba [34]: 17).

Itulah sebagian makna firman Allah yang sangat populer: "Jika kamu bersyukur pasti akan Kutambah (nikmat-Ku) untukmu, dan bila kamu kufur, maka sesungguhnya siksa-Ku amat pedih (QS Ibrahim [14]: ayat 7).

Adapun bersabar dengan perbuatan adalah berusaha sekuat tenaga dan perasaan untuk tetap mengendalikan nafsu ammarahnya agar tidak melakukan hal-hal yang menyimpang dari ketentuan Allah dan Rasul-Nya. Secara praktis dianjurkan untuk mengambil air Wudhu, karena marah itu dianalogikan oleh Rasulullah Saw. sebagai api yang bisa dipadamkan dengan air yakni berwudhu.

\section{Pertemuan Sabar dan Syukur}

Sebagaimana telah kita maklumi bersama bahwa keadaan orang yang bersabar dan bersyukur itu adalah berbeda apabila dilihat secara zahirnya, karena sabar secara rasional merupakan aktualisasi atau sikap dari perasaan sempit atau menyesakkan atas diri. sementara Syukur adalah sebaliknya, ia merupakan sikap atau pernyataan dari perasaan seseorang yang dalam keadaan gembira dan menyenangkan. Akan tetapi yang perlu kita garis bawahi adalah kedua sikap itu ada dalam qalbi/hati setiap orang.

Dengan kata lain, dua perasaan tersebut dapat dikeluarkan berdasarkan keadaan yang mengitarinya walaupun harus diakui keduanya bersumber dari dalam hati yang satu. Oleh karena itu Rasulullah Saw. sendiri menggaris bawahi bahwa hal tersebut menjadi sesuatu yang ajaib bagi orang yang beriman. 


\section{Keajaiban Sabar dan Syukur bagi orang beriman}

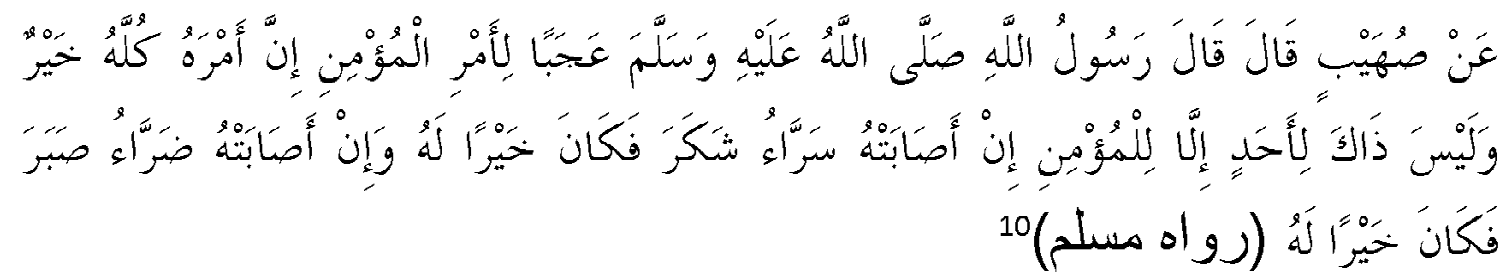

"Dari Shubaib beliau berkata: Rasulullah Saw. bersabda: "Ajaib bagi perkara orang mu'min, sesungguhnya seluruh problematikanya adalab baik, dan tidak ada seorangpun mendapatkan hal seperti itu kecuali bagi orang yang beriman; Jika menimpanya kesenangan ia bersyukur, maka bal itu adalah baik baginya. Dan jika menimpanya kesempitan iapun bersabar, maka itu adalab baik baginya" (HR. Muslim).

Manusia seringkali berlaku egois.Ketika menginginkan sesuatu, dia berdoa habis-habisan, sungguh-sungguh demi tercapai keinginannya.Tatkala berhasil, dia melupakan Allah.Bahkan dia menganggap bahwa keberhasilan itu adalah hasil jerih payahnya sendiri.Sebaliknya, saat dia gagal, dia kecewa karenanya, bahkan berburuk sangka kepada Allah SWT.Padahal rasa kecewa, sedih, dan kesal itu lahir karena manusia terlalu berharap bahwa kehendak Allah harus cocok dengan keinginannya.

Oleh karena itu dalam buku "Dahsyatnya Sabar"11 ada cara menerapkan sabar dalam kehidupan sehari-hari, yaitu: 1) Teguh pada prinsip; 2) Tabah; 3) Tekun; 4) Tidak cepat putus asa; dan 5) Tahapan menuju sukses

\section{Romantika Sabar dan Syukur dalam Kehidupan}

Pernahkah kita mengamati sepasang keluarga bahagia disekitar, setidaknya dilihat melalui pengamatan kaca mata pribadi sebagai seorang sahabatnya, teman dekatnya atau orang-orang memang mengenalnya terhadap kondisi pasangan tersebut.

Disepakati bahwa pasangan suami isteri yang bahagia adalah pasangan yang dikaruniai kenikmatan tiada tara yaitu keluarga yang Sakinah,MawadabWarahmah, dapat terlihat dari ekspresi kedua pasangan suami isteri yang terlihat cerah, berbinar dan tidak melupakan senyum selalu terulas dibibir keduanya namun tanpa melepas akan beramal ibadah sesuai syariat bahkan tidak menutup kemungkinan suatu saat dapat memperlihatkan ekspresi luapan kegembiraan yang tidak dapat disembunyikan yaitu linangan air mata sampai menangis tersedu tanda kebahagiaan yang tiada tara.

Ada perasaan yang tidak dapat terbendung ketika sesampainya di rumah yang asri, di dalam rumah yang tertata rapi sang suami langsung mencari isterinya, nampak ia sedang menunggu kedatangannya dimeja makan dengan senyum semringah terulas dibibirnya yang mungil, dengan nada tersendat dan linangan air mata sang suami menceritakan kegiatan yang barusan dilihat di kantornya, bukan karena ketidak hadirannya yang membuat air matanya

\footnotetext{
${ }^{10}$ Abi al-Husayn Muslim b. al-Hajjaj b. Muslim, Sabih Muslim, kitab al-imarah, bab bayan al-Mu'min Amrubu Kullubu Khayr, (Bayrut: Dar al-Ihya' al-Turath al-'Arabi, t.th, Juz 14.), h. 280. Hadits ini juga dimasukkan oleh al-Abani dalam alSilsilah al-Sahihahnya, No. 147.
} 
meleleh, atau menanyakan kenapa Mamah tidak bisa hadir dalam moment penting photo bersama isteri-isteri pegawai serta seluruh karyawati di perusahaan dimana suaminya bekerja, tetapi justeru beliau terharu sambil berucap Syukur karena baru pertama kali menyadari bahwa isterinya ternyata paling cantik.

Mendengar reaksi spontan dari sang suami yang tiba-tiba saja sesampainya di rumah ujugujug memeluk sambil berlinang air mata, keadaan tersebut membuat sang isteri juga menjadi larut, turut terharu betapa suaminya baru menyadari bahwa dirinya memang seorang perempuan yang paling cantik padahal ia sudah cukup lama bersabar mendampingi suaminya yang kondisinya dibawah rata-rata pria pada umumnya, peluk mesra kedua pasangan tersebut menyiratkan sisi romantis kebahagiaan rumah tangga.

Syukur dan Sabar ternyata merupakan perpaduan yang teramat indah dalam mahligai keluarga Sakinah Mawadah Warokhmah.

Resep pasangan berbahagia ternyata hanya pandai bersyukur dan pandai bersabar.'Dua hal yang akan menghampiri orang-orang yang mengharapkan kebahagiaan yaitu Pandai bersyukur dan pandai bersabar ". "Lantas kenapa dengan dua hal tersebut"?

Bersyukur tidak hanya sebatas kata-kata yang selalu diucapkan ketika mendapatkan kelapangan, Bersyukur esensinya jauh dari pada itu karena ada keterlibatan rasa terimakasih dan penghargaan yang mendalam terhadap pemberian Allah SWT kepada umatnya, walau apapun bentuk dan rupa pemberian tersebut.

Seperti biasanya kadang tanpa terperhatikan bahwa karunia dan nikmat Allah itu bertebaran di sekeliling kita, jangankan akan jaminan Allah yang akan memberikan rezeki ketika kita dengan sungguh-sungguh mencarinya, bahkan udara (oksigen) yang kita hirup pun demikian berlimpah tersedia disekeliling kita dengan gratis. Jadi Nikmat apa lagi yang kau ingkari. Bersyukur merupakan hal yang wajib bagi umat sebagai media pembuka pintu rezeki dan nikmat yang akan lebih berlimpah lagi sebagaimana dalam firmanNya:

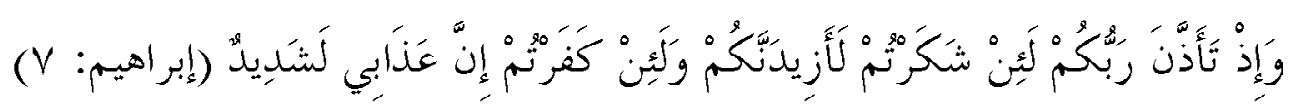

"Dan (ingatlah juga), tatkala Tuhanmu memaklumkan: "Sesunggubnya jika kamu bersyukur, pasti Kami akan menambah (nikmat) kepadamu.” (QS. Ibrahim: 7)

Sabar adalah: Menahan diri dari sifat kegundahan dan rasa emosi, kemudian menahan lisan dari keluh kesah serta menahan anggota tubuh dari perbuatan yang tidak terarah.

Kesabaran merupakan salah satu ciri mendasar orang yang bertaqwa kepada Allah SWT. Bahkan sebagian ulama mengatakan bahwa kesabaran merupakan setengah dari iman ${ }^{12}$. Sabar memiliki kaitan yang tidak mungkin dipisahkan dari keimanan: Kaitan antara sabar dengan iman, adalah seperti kepala dengan jasadnya. Tidak ada keimanan yang tidak disertai kesabaran, sebagaimana juga tidak ada jasad yang tidak memiliki kepala.Oleh karena itulah Rasulullah Saw.menggambarkandengan jelas tentang ciri dan keutamaan orang yang beriman sebagaimana

${ }^{11}$ Hadi Yasin, Ahmad, DahsyatnyaSabar, (Jakarta: Qultum Media, 2008.), h. 25

${ }^{12}$ Al-Imam Abu Hamid Muhammad bin Muhammad al-Ghazali, Ibya 'Ulum al-Din, (Surabaya: Dar al-Nasyr alMashriyyah,Juz. Ke-4, t.th.), h. 59. bahwa beliau menyatakan hadits tentang iman itu ada dua bagian, sebagiannya Sabar dan sebagian yang lain adalah Syukur. 
dalam hadits-haditsnya.

Seorang Mukmin jika mendapatkan suatu musibah, bencana, rasa duka, sedih, kemalangan dan hal-hal negatif lainnya, ia akan bersabar. Karena ia meyakini bahwa hal tersebut merupakan pemberian sekaligus cobaan bagi dirinya yang pasti memiliki rahasia kebaikan di dalamnya. Sehingga refleksinya adalah dengan bersabar dan mengembalikan semuanya kepada Allah Swt.

Pengakuan seorang manusia bahwa dia adalah mahluk yg lemah "nol (0)" dan hanya Allah penolong bagi mahluknya.." dan katakan Tuhan itu Satu dengan "Syukur"dalam arti berupaya dan berusaha untuk jauh lebih baik dari keadaan sebelumnya "jika kamu bersyukur maka akan ditambah nikmatnya"

Jadi sabar itu akan bernilai jika sudah ada usaha dan yakin semua ini ada yg mengatur dan memang sangat benar jika "Sesungguhnya Allah mencintai orang yang sabar" karena hasil itu dari usaha adalah bonus, sementara dalam proses dengan penuh kesabaran itu adalah kenikmatan sejati.

Sebuah dinamika dalam kehidupan manusia, naik turunnya status social di masyarakat, kaya dan miskin, susah dan senang bukan berarti menjadi standar nilai di hadapan Allah Swt., tapi sebagai ujian apakah orang yang kaya senantiasa mendermawankan hartanya untuk di jalan Allah Swt. atau tidak. Begitu pula dengan orang miskin, apakah mereka selalu senantiasa sabar dan ikhlas dalam setiap menerima cobaan yang diberikan Allah Swt. kepada dirinya.

\section{Penutup}

Sabar bukan berarti berhenti dan diam tapi sabar adalah berhenti sejenak dan segera bergerak cepat melakukan perubahan ke arah yang lebih baik, Karena hidup tanpa masalah hanyalah sebuah perjalanan yang sepintas dilalui tanpa tahu apa saja keindahan yang ada di sekitarnya.

Setiap insan yang hidup di muka bumi ini pasti pernah mengalami suka dan duka. Tak ada insan yang diberi duka sepanjang hidupnya, karena ada kalanya kemanisan hidup menghampirinya. Demikian pula sebaliknya, tak ada insan yang terus merasa suka karena mesti suatu ketika duka menyapanya. Bila demikian tidaklah salah pepatah yang mengatakan, "Kehidupan ini ibarat roda yang berputar", terkadang di atas, terkadang di bawah. Terkadang bangun dan sukses, terkadang jatuh dan bangkrut, kadang kalah, kadang menang, kadang susah, kadang bahagia, kadang suka dan kadang duka.

Sedikit sekali dari hamba-hamba-KU yang tahu bersyukur (QS, 34:13). Bersyukurlah kepada Allah. Dan barangsiapa yang bersyukur (kepada Allah), maka sesungguhnya ia bersyukur untuk dirinya sendiri; dan barangsiapa yang tidak bersyukur, maka sesungguhnya Allah Maha Kaya lagi Maha Terpuji.” (Luqman, 31:12)

Syukur dan Sabar ternyata merupakan perpaduan yang teramat indah dalam mahligai keluarga Sakinah MawadabWarokhmah, jadi upayakanlah agar sabar dan syukur itu selalu bersemi di dalam hati kita masing-masing. Pada mulanya memang keduanya hanyak saling menyapa saja, namun seiring dengan waktu seharusnya menjadi dua kekuatan yang hebat dalam rangka mengarungi keras dan tingginya persaingan hidup dan kehidupan di dunia pana ini, agar pandangan batinnya tertuju kepada Sang Pemberi Ni'mat dan Sang Penguji yang Maha tahu kapasitas semua hamba-Nya. 
Dengan demikian bersyukur dan bersabarlah dengan sepenuh hati, dilafazkan secara lisan dengan ungkapan al-hamdulillah sebagai pernyataan syukur dan Inna Lillah wa inna ilaibi rajïun sebagaipernyataan bersabar dan selanjutnya harus diimplementasikan dalam bentuk perbuatan insya Allah.

\section{DAFTAR PUSTAKA}

al-Albani, Muhammad Nasir al-Din, (t.th.). Silsilat al-Ahadith al-Sabihah, al-Riyad: Maktabah al-Macarif li al-Nashr wa al-Tawzi.

al-Ashfahani, al-Raghib,(t.th.). Mu'jam Mufradat AlFazh al-Qur'an, Beirut: Dar al-Fikr.

al-Ghazali, al-Imam Abu Hamid Muhammad bin Muhammad, (2002). Kitab al-Arba'in fi Ushul al-Din, Terj. Rojaya, 40 Prinsip Agama, Bandung: Pustaka al-Hidayah.

-, (t.th.). Ibya Ulum al-Din, Juz. Ke-4, Surabaya: Dar al-Nasyr al-Mashriyyah.

Hadi Yasin, Ahmad, (2008). DahsyatnyaSabar, Jakarta: Qultum Media.

Imam Ibrahim bin Umar al-Biqa'i, (tth). Ną̧hm al-Durar fi Tanasub al-Ayat wa al-Suwar, t.tp, Dar al-Kitab al-Islamy.

Ibn Faris, Abu Husayn Ahmad bin Faris bin Zakariya, (1411 H/1991 M). Mujjam Maqayis alLughah, Bayrut: Dar al-Jalil, Jilid II.

K.H. Mmuhammad Bakhit, Ibn al-Mukarram K.H. Ahmad Mughni, Mengenal al-Asma' al-Husna: Jalan Menuju Ma'rifat Allah Swt,Barabai HST: Pon. Pes. Dan Majlis Ta'lim Nur alMuhibbin.

Muslim, Abi al-Husayn Muslim b. al-Hajjaj, Imam, (t.th.). Sabih Muslim, kitab al-imarah, bab bayan al-Mu'min Amrubu Kullubu Khayr,Juz 14, Bayrut: Dar al-Ihya' al-Turath al-'Arabi.

Al-Rifa'i, Muhammad Nasib, (1999). Kemudahan dari Allah, Ringkasan Tafsir Ibnu Katsir, Riyadh: Maktabah al-Ma'arif, danJakarta: Gema Insani.

al-Qusyairy, Al-'Allamah al-'Arif billah Abi al-Qasim 'Abdul Karim bin Hawazin al-Naisaburi, (t.th.). al-Risalah al-Qusyairiyyahfi Ilm al-Tashawnuf, t.tp. Dar al-Khair. 